\title{
A Eterna Luta Contra a Sombra da Tortura e dos Crimes Políticos Sofridos, em Defesa da Dignidade Humana
}

\begin{abstract}
Leticia Facci Castro
Graduação em Direito pela Unicesumar - Centro Universitário de Maringá/PR. Pós-Graduação em Direito Notarial e Registral pela LFG (Luiz Flávio Gomes). Pós-Graduação em Direito Público pela Damásio Educacional. Mestrado em Direitos da Personalidade pela Unicesumar. Advogada regularmente inscrita na OAB-PR 86.511. http://lattes.cnpq.br/5176002759615419. https://orcid.org/0000-0003-4950-7833. leticiafaccidecastro@hotmail.com

\section{Cleide Aparecida Gomes Fermentão}

Doutorado em Direito das Relações Sociais pela Universidade Federal do Paraná - UFPR (2004). Pós-Doutorado em Hermenêutica Jurídica pela Universidade Vale dos Sinos (Unisinos-RS). Mestrado em Direito Civil pela Universidade Estadual de Maringá-PR (UEM, 2001). Graduação em Direito pela Universidade Estadual de Maringá (1977). Professora titular da Graduação e do Programa de Mestrado e Doutorado da Unicesumar - Centro Universitário de Maringá. Membro do Instituto dos Advogados do Paraná (IAP) e do Instituto Brasileiro de Direito de Família (IBDFAM). Pesquisadora do Iceti. Advogada. http://lattes.cnpq.br/4532145888110686. https://orcid.org/0000-0002-7121-5565. cleidefermentao@gmail.com
\end{abstract}

A tortura é uma forma degradante de violação aos direitos humanos e da dignidade humana, com prisões e condenações sumárias sem o direito ao contraditório, prisões ilegais, torturas, mortes e pessoas desaparecidas por crimes políticos e conexos. A Lei da Anistia consistiu em uma espécie de perdão a todos aqueles que cometeram crimes considerados pelo Estado como atentatórios à dignidade da pessoa humana, no período de 1961 a 1979, fazendo com que as violações aos direitos humanos ocorridas na época, ficassem sem punição por parte do Estado, a partir do momento em que a lei passou a vigorar no ordenamento pátrio, em 1979. Mesmo diante de uma ADPF questionando a revalidação da lei 6.683/79, e a condenação do Estado brasileiro por parte da Corte Interamericana, a lei não foi retirada do ordenamento, com seus efeitos repercutindo até os dias atuais. É preciso analisar quais normas, convenções e declarações internacionais foram infringidas com a tortura no período ditatorial e quais os efeitos nocivos à vida humana. Danos físicos, morais, psíquicos e mentais foram causados às vítimas em um período de escuridão nos direitos, quando o poder massacrou aqueles que se colocaram contrários ao mesmo, e as torturas foram aplicadas, criando a desesperança, a perda da liberdade, da vida e da dignidade.

Palavras-chave: Tortura. Anistia. Tratados Internacionais. Direitos constitucionais. Dignidade humana.

THE ETERNAL FIGHT AGAINT THE SHADOW OF TORTURE AND CRIME SUFFERED POLITICIANS IN DEFENSE OF HUMAN DIGNITY

From the moment in which a State demonstrates interest in participating in an International Agreement, it is extremely important to demonstrate it, and, under the International Law, carry out the process to actually internalize the International document. After ratification, according to the 1969 Vienna Convention, there is no need to talk about refusing in an agreement compliance, under the international mismatch justification with the system, since the International Law overlaps the internal order. In 1984, there was a celebration by the UN Convention against torture and other cruel, inhuman or degrading treatment as a way of protecting all those who passed through this kind of situation. Nevertheless, in Brazil, the Law no 6683/7 gave amnesty to all those who had committed political crimes and related to them, within the time stipulated by it. The purpose of this research refers to the accession agreement clarification by State will manifestation, and its non full compliance by the Judicial System, since there are regulatory dictates that do not match the ratified Convention and its consequent International accountability. The proposed methodology for it will be through bibliographical and documentary research, using the dialectical method, promoting a distinction between stages of an agreement and its concrete application, with the objective of better analyzing the issue.

Keywords: Torture. Amnesty. International Agreement. State Responsibility. Dictatorship. Impunity.

SUMÁRIO

1 Introdução. 2 Do período das nuvens escuras no brasil: a tortura e os crimes políticos. 3 Tortura e crimes políticos: uma realidade acobertada bela anistia. $4 \mathrm{~A}$ postura internacional e a comissão contra a tortura. 4.1 Tratados internacionais: a recepção voluntária, a sua necessária vinculação depois que são ratificados e o controle internacional. $4.2 \mathrm{~A}$ incompatibilidade da convenção internacional com a Lei da Anistia. 5 Arguição de descumprimento de preceito fundamental 153. 5.1 Caso Gomes Lund - o Reconhecimento da Responsabilidade Brasileira e a Falta de Adequação das Decisões com a Convenção Internacional Ratificada. 7 A anistia na jurisprudência atual. 8 Conclusão. 9 Referências. 


\section{INTRODUÇÃO}

Desde os mais remotos tempos, a tortura destacou-se como uma das formas degradantes de violação aos direitos humanos e à dignidade humana. Ao término da Segunda Guerra Mundial, a humanidade ficou estarrecida pela crueldade sofrida nos campos de concentração e as crueldades gerais praticadas, levando os países a criar a ONU. Em 1948 foi estabelecida a Declaração Universal dos Direitos Humanos, com a proteção à dignidade humana.

O Brasil viveu um longo período de ditadura militar, quando os direitos à proteção à dignidade humana foram afrontados com prisões e condenações sumárias, sem o direito ao contraditório, prisões ilegais, torturas, mortes e pessoas desaparecidas por crimes políticos e conexos, em total confronto ao respeito e proteção à dignidade humana, mesmo estando em esfera internacional tal direito protegido pela Declaração Universal dos Direitos Humanos.

A Lei 6.683/79 concedeu a anistia a todos quantos, no período compreendido entre 2 de setembro de 1961 e 15 de agosto de 1979, cometeram crimes políticos ou conexo com estes, crimes eleitorais, aos que tiveram seus direitos políticos suspensos e aos servidores da Administração Direta e Indireta, de fundações vinculadas ao poder público, aos servidores dos Poderes Legislativo e Judiciário, aos militares e aos dirigentes e representantes sindicais, punidos com fundamento em Atos Institucionais e Complementares.

Diversos episódios de tortura tornaram-se incontroversos na história, e, em consideração a isto, a primeira Convenção específica da ONU - Assembleia Geral das Nações Unidas -, em sua XL Sessão, realizada em Nova York, posicionou-se, em data de 10 de dezembro de 1984, contra a Tortura e Outros Tratamentos ou Penas Cruéis, Desumanos ou Degradantes. No direito pátrio, o Decreto Legislativo n. 4, de 23 de maio de 1989, aprovou a mencionada convenção. O Decreto n. 40, de 15 de fevereiro de 1991, promulgou a convenção contra a tortura e outros tratamentos ou penas cruéis, desumanos e degradantes. A Lei 9.455/97 estabeleceu o crime de tortura e as penas a serem aplicadas, verdadeira luz para um calabouço de dor e medo.

As nuvens escuras da ditadura e da tortura no Brasil por crimes políticos sempre estiveram à espreita, nunca totalmente dissipadas, diante de gritos desconexos e de pessoas com vendas nos olhos que tentam reviver tal período negro da história. Assim, diante do atual contexto social e histórico, é necessário fazer uma análise crítica de tal período vivido, quando os direitos humanos foram aviltados e o Estado brasileiro, somente com a Constituição Federal promulgada em 1988, consagrou o Princípio da Defesa da Dignidade Humana. A Lei da tortura, 9.455/97, consagrou a defesa da dignidade humana, ao estabelecer a tortura como crime e estabelecendo as penas aos pratricantes de tal crime.

\section{DO PERÍODO DAS NUVENS ESCURAS NO BRASIL: A Tortura e os Crimes Políticos}

Dentro do contexto brasileiro à época, a anistia consistiu em uma espécie de perdão a todos aqueles que cometeram crimes políticos e conexos durante o período de 2 de setembro de 1961 a 15 de agosto de 1979. Apenas os que já haviam sido condenados pelos crimes cometidos (como a prática de terrorismo, assalto, sequestro e atentado pessoal) ficaram de fora da lei. A anistia para o direito pátrio e os atos que a validaram, foram recepcionados por diversos estados latino-americanos, cada qual à sua maneira, em momentos em que os países 


\section{Humanos e \\ Democracia}

se encontravam em transições democráticas. ${ }^{1}$ Nestes, é possível uma percepção, por meio das decisões proferidas pela Corte Interamericana de Direitos Humanos, ${ }^{2}$ que a anistia se tornou uma maneira de inércia diante da responsabilização por parte do Estado, dos violadores de direitos, bem como da dignidade da pessoa humana. A anistia, ao mesmo compasso que perdoava por um determinado período aqueles que praticaram os crimes políticos e conexos, deixava de condenar aqueles que praticavam a tortura.

Toda a América Latina vivia um período conturbado em razão de governos ditadores. 0 Brasil, no período compreendido entre 1964 e 1985, enfrentou um regime militar de extremo desrespeito e violação a todos os direitos inerentes à pessoa humana. Violações estas que passaram desde a vedação à liberdade na imprensa, a desaparecimentos forçados e tortura. O ano de 1968 foi um período conhecido como "anos de chumbo", em que as repressões, bem como as violações dos direitos humanos, chegaram ao seu mais alto grau, sob a vigência do Al-5 (Ato Institucional n. 5 da Presidência da República), que suspendeu diversas garantias constitucionais. Naquele momento, tornou-se comum o desaparecimento de todos aqueles que eram contrários ao regime militar que governava o país.

Conforme registros da Comissão Especial Sobre Mortos e Desaparecidos Políticos,

é certo que nos três primeiros anos de Geisel, os interrogatórios mediante tortura e a eliminação física dos opositores políticos continuaram sendo rotina. $O$ desaparecimento de presos políticos, que antes era apenas uma parcela das mortes ocorridas, torna-se regra predominante para que não ficasse estampada a contradição entre discurso de abertura e a repetição sistemática das velhas notas oficiais simulando atropelamentos, tentativas de fuga e falsos suicídios. ${ }^{3}$

Com uma população descontente surgiram movimentos pelo país, nos quais esta se rebelou contra a ditadura imposta, contra a tortura, a falta de liberdade de expressão, o direito ao contraditório e demais direitos. Tais movimentos eram perseguidos. A luta era contra o regime militar. O caso mais conhecido, entre estes, foi a intitulado "Guerrilha do Araguaia", que resultou no desaparecimento forçado, detenção arbitrária e tortura de mais de 70 pessoas. Os integrantes do partido PC do B (Partido Comunista do Brasil) eram perseguidos e torturados. Sobre o caso, a Comissão Especial sobre Mortos e Desaparecidos Políticos, traz:

No final de 1973, último ano de Médici, já estava evidente o esgotamento do chamado "Milagre Brasileiro", ciclo de cinco anos com forte crescimento do PIB, e os grupos militares de origem castellista conseguiram recuperar força, impondo Ernesto Geisel como próximo presidente. No momento de sua posse, em março de 1974, os órgãos de repressão já tinham logrado êxito no combate aos grupos de guerrilha urbana e desenvolviam a última campanha militar de aniquilamento contra os militantes do PCdoB no Araguaia. ${ }^{4}$

\footnotetext{
MAZZUOLI, 2014, p. 267.

2 Por exemplo, nos casos Barrios Altos vs. Peru, Almonacid Arellano e outros vs. Chile (2006) e Gomes Lund e outros vs. Brasil (2010)

Secretaria Especial dos Direitos Humanos, 2007, p. 33.

Secretaria Especial dos Direitos Humanos, 2007, p. 33.
} 
A oposição ao governo mobilizava-se para que fosse aprovada a anistia "ampla, geral e irrestrita", e concedido a todos aqueles considerados presos políticos, exilados e cassados, o perdão de tais atos, considerados, até então, conduta contra o Estado. Durante o governo sucessor de João Figueiredo, no ano de 1979, foi concedida anistia a todos aqueles que estavam envolvidos em crimes políticos e conexos a este, no período estipulado pelo mesmo. Esta, em sua interpretação literal, deu a absolvição a todos os agentes que cometeram violações aos direitos humanos, presos e exilados políticos. ${ }^{5}$ Trata-se de uma espécie de autoanistia do próprio regime, de modo que não existisse uma perseguição nas violações que ocorreram em todo o território.

O artigo primeiro da Lei $n=6.683 / 79$ assim explicava:

Art. 10 É concedida anistia a todos quantos, no período compreendido entre 02 de setembro de 1961 e 15 de agosto de 1979, cometeram crimes políticos ou conexo com estes, crimes eleitorais, aos que tiveram seus direitos políticos suspensos e aos servidores da Administração Direta e Indireta, de fundações vinculadas ao poder público, aos Servidores dos Poderes Legislativo e Judiciário, aos Militares e aos dirigentes e representantes sindicais, punidos com fundamento em Atos Institucionais e Complementares (vetado).

$\S 1$ - Consideram-se conexos, para efeito deste artigo, os crimes de qualquer natureza relacionados com crimes políticos ou praticados por motivação política.

$\S 2$ - Excetuam-se dos benefícios da anistia os que foram condenados pela prática de crimes de terrorismo, assalto, seqüestro e atentado pessoal.

$\S$ 3o - Terá direito à reversão ao Serviço Público a esposa do militar demitido por Ato Institucional, que foi obrigada a pedir exoneração do respectivo cargo, para poder habilitar-se ao montepio militar, obedecidas as exigências do art. 3‥ ${ }^{6}$

Aqueles que já se encontravam condenados no momento da criação da mencionada lei, não foram abrangidos pela anistia. ${ }^{7}$ Quantas pessoas já haviam sofrido as consequências de discordar dos atos praticados pelo Estado? Quantas estavam enterradas em valas sem qualquer identificação após terem sofrido torturas por não concordarem com a ditadura militar? Evidentemente que estes foram amordaçados em seus direitos humanos, sofrendo pela ausência de liberdade de expressão, e sua vida e dignidade foram feridas.

\section{TORTURA E CRIMES POLÍTICOS: Uma Realidade Acobertada Pela Anistia}

A tortura e os crimes políticos são objetos de exaustiva discussão acadêmica e são os principais temas abordados pela Lei da Anistia. Crimes políticos, de acordo com Cretella Júnior, são "todos aqueles que lesam, ou colocam na iminência de lesão, a soberania, integridade, a estrutura constitucional ou o regime político do Brasil". ${ }^{8}$ A partir de 1964 o poder do Estado e a sua soberania eram afetados por qualquer ato ou fala que fosse contrário ao mesmo. Todos os atos, por serem proibidos por lei, eram considerados atos de lesão e terrorismo ao Estado. Para apurar tais condutas, eram praticadas a tortura e as prisões ilegais, sem ordem

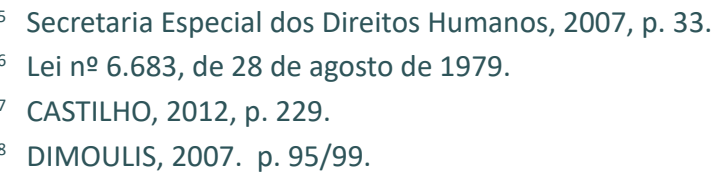




\section{Democracia}

judicial, com torturas cruéis e desumanas. A tortura teve a sua definição com a Convenção Internacional Contra a Tortura e Outras Penas ou Tratamentos Cruéis, Desumanos e Degradantes, de 1984, em seu artigo 1., alínea 1:

o termo tortura designa qualquer ato pelo qual dores ou sofrimentos agudos, físicos ou mentais, são infligidos intencionalmente a uma pessoa a fim de obter, dela ou de uma terceira pessoa, informações ou confissões; de castigá-la por ato que ela ou uma terceira pessoa tenha cometido, ou seja, suspeita de ter cometido; de intimidar ou coagir esta pessoa ou outras pessoas; ou por qualquer motivo baseado em discriminação de qualquer natureza, quando tais dores ou sofrimentos são infligidos por um funcionário público ou outra pessoa no exercício de funções públicas, ou por sua instigação, ou com o seu consentimento ou aquiescência.

A tortura está relacionada à dor física e mental do torturado, com o objetivo de obter informações ou confissões. Para o castigo por atos do torturado ou de terceiros, bastava a suspeita por tal cometimento. A intimidação era por meio de coação física e moral, afogamentos, castigos com choques elétricos em partes íntimas, espancamentos e utilização do temido "pau de arara", no qual a pessoa tinha amarrados as mãos e os pés, posição que a deixava totalmente vulnerável a estupros e violências de todas as formas.

Após 28 anos da publicação da Lei da Anistia, foi realizado o relatório final da Comissão Especial sobre Mortos e Desaparecidos Políticos, que buscava trazer luz ao período de sombras e mordaças, e conseguir as informações sobre as violações aos direitos humanos ocorridas no ciclo ditatorial. Este somente foi possível em razão de um projeto que transformou em lei a comissão especial, de modo que fosse buscada uma reparação indenizatória aos sobreviventes e familiares, com a localização de restos mortais, valendo-se da tecnologia (exames de DNA), o que possibilitou encontrar enterrados em valas comuns e sem qualquer identificação, pessoas até então consideradas desaparecidas.

Muitos torturados sobreviveram aos castigos, outros conseguiram manter-se calados mesmo diante das torturas cruéis; outros, em razão das torturas, sofreram danos mentais irreversíveis, perda da memória e do discernimento e problemas psicológicos, frutos da violação aos direitos humanos sofridos. Estes, de início tiveram uma grande resistência quanto a sua investigação, uma vez que, de imediato, os envolvidos e familiares possuíam apenas versões contadas, sem qualquer tipo de prova documental comprobatória, contando, ainda, com a ameaça de novas violações, caso os fatos fossem revelados. Ao todo, passaram-se 35 anos de tentativas frustradas, que chegaram a um maior avanço apenas quando o Brasil reconheceu a sua responsabilidade. Dificuldade essa que se iniciou na Lei da Anistia, conforme os dizeres da comissão:

A legítima pressão exercida por militantes dos Direitos Humanos, ex-presos políticos, exilados, cassados e familiares de mortos e desaparecidos a favor da Anistia e do direito à verdade adquiriu vigor em meados da década de 1970, até resultar na conquista da Lei no 6.683, de 28 de agosto de 1979, conhecida como Lei da Anistia.

Até os dias atuais a Lei 6.683 , de 1979 , gera controvérsias em sua interpretação ao absolver todas as violações de direitos humanos. O próprio artigo 10 abriu uma margem de interpretação imensa, quando abrangeu também os crimes conexos aos políticos. 
O sistema à época criou formas de prisão e maneiras de manter as pessoas presas, chamados de presos políticos. Muitas pessoas que foram retiradas à força de seus domicílios, diante da dor e do sofrimento de suas famílias, sem ordem judicial, foram presas em lugares ermos, desconhecidos, e jamais voltaram. Pesquisa realizada constatou processos políticos que tramitaram perante a justiça militar, com relatos das repressões e torturas que ocorreram pelo Brasil no período de 1964 a 1979. Diante de tais pesquisas e relatos é possível ter-se uma ideia de fato do que foi o período de repressão vivido no país, e as diversas maneiras em que violações aos direitos humanos ocorreram. Todos esses crimes foram acobertados pela Lei da Anistia.

Maria do Carmo Souza relata a prisão sofrida por cinco homens que invadiram a residência de seus pais onde se encontrava; ela foi encapuzada e conduzida para o II Exército, tendo sido dito à mesma que naquele lugar teria falecido Vladimir Herzog:

.... que, tão logo lá chegou, foi despida, amarraram-lhe panos molhados num dos braços e num dos tornozelos; que depois de receber um balde d'água que lhe foi atirado, passou a sofrer choques elétricos, querendo os torturadores com isso que a interrogada se incriminasse, admitindo sua participação numa organização política; que, nos três dias em que lá ficou, sofreu torturas psicológicas, foi espancada (...) que, com o capuz um pouco levantado, durante a viagem para o Rio, conseguiu identificar que foi conduzida para o DOI-CODI, onde passou pelas mesmas sevícias e vexames.(...). ${ }^{9}$

A Lei da Anistia fechou as portas para a investigação do comportamento do Estado nos casos de tortura e castigos cruéis. A Lei da Anistia era um apagar da história a crueldade praticada, sem remorsos, sem qualquer responsabilidade por tais atitudes, que feriu o direito à vida, à liberdade, à dignidade humana. $\mathrm{O}$ direito à investigação por atos cruéis ficou calado, gerando uma mancha no direito.

\section{A POSTURA INTERNACIONAL E A COMISSÃO CONTRA A TORTURA}

As violações aos direitos humanos ocorreram ao redor de todo o mundo desde os tempos mais remotos. Pode-se afirmar que a tortura é uma das formas mais repugnantes e degradantes a que a pessoa humana é sujeita, por atos do Estado, para uma confissão de crime supostamente cometido. A tortura possui um efeito negativo nas vítimas, uma destruição moral, emocional, psíquica, quando sobrevivem à mesma. Diante de tais comportamentos, a ONU discutiu o tema em sua primeira Convenção internacional, em busca de uma forma de proteção aos direitos humanos e à própria dignidade do ser.

No ano de 1984 foi celebrada pela ONU a Convenção contra a tortura e outros tratamentos ou penas cruéis, desumanos ou degradantes, fazendo com que todos aqueles que passavam ou passam por qualquer tipo de danos para a sua dignidade, recebessem uma atenção especial no quesito proteção, e punibilidade ao agente ativo. Ainda, foi criado o Comitê contra a Tortura, para investigar qualquer denúncia ou iminência desta. $O$ texto da Convenção

ARNS, 2001, p. 86-87 


\section{Democracia}

Humanos e

foi dividido em partes, de maneira que os sujeitos ativos e passivos sejam identificados, bem como delimitados os procedimentos a serem realizados após a sua adesão, a formação de um comitê e o seu funcionamento, e, por fim, a adesão dos Estados à Convenção.

Tal convenção destaca a possibilidade de responsabilização do Estado em razão dos atos realizados pelos funcionários públicos, mesmo que diante de ordens superiores. Ao todo foram 24 artigos que a compuseram, e não mais fizeram do que esclarecer todo e qualquer procedimento que deverá ser tomado em casos de tortura ou tratamentos degradantes. Ainda ressaltou que não existem possibilidades de justificativas em situações como esta, até mesmo em casos de guerra - conforme o artigo 50 da mesma. ${ }^{10}$ É importante ressaltar que, como forma de manter o tratamento igualitário no procedimento, assim como todos os direitos pessoais e intransferíveis da pessoa humana, as garantias processuais do suposto autor do delito em questão não foram retiradas pela Convenção; assim, todos os princípios constitucionais e protetores da dignidade humana devem ser respeitados. A jurisdição interna dos países não foi excluída.

Como exemplo dessa continuidade dos princípios internos compatíveis com a Convenção, conforme o artigo 13, os delitos ressaltados nesta são passíveis de extradição, mesmo entre um Estado parte e aquele com o qual não tiver tratado, vigendo o princípio da universalidade. A Convenção será o suporte para o procedimento da extradição. ${ }^{11}$

Com o advento da Constituição de 1988, antes mesmo da ratificação do tratado, passou-se a priorizar a dignidade da pessoa humana como um dos fundamentos basilares de todo o ordenamento jurídico brasileiro, fazendo com que, conforme o artigo 5o, III da CF/88, a tortura entrasse para o rol dos crimes hediondos, tornando-a insuscetível de fiança, graça ou anistia. O referido dispositivo constitucional possui a previsão de que "ninguém será submetido a tortura ou a tratamento desumano ou degradante". Aqui, o ordenamento parecia estar adequando-se aos ditames internacionais, deixando para trás um período ditatorial e violador de direitos humanos.

\footnotetext{
${ }^{10}$ Convenção contra a tortura e outros tratamentos ou penas cruéis, desumanos ou degradantes adotada pela Resolução 39/46, da Assembleia Geral das Nações Unidas, em 10 de dezembro de 1984. Os Estados Partes nesta Convenção, considerando que, de acordo com os princípios proclamados na Carta das Nações Unidas, o reconhecimento dos direitos iguais e inalienáveis de todos os membros da família humana constitui o fundamento da liberdade, da justiça e da paz no mundo, reconhecendo que estes direitos derivam da dignidade inerente à pessoa humana, considerando a obrigação dos Estados, nos termos da Carta, especialmente do artigo 55, de promover o respeito universal e a observância dos direitos humanos e das liberdades fundamentais, tendo em conta o artigo 5 da Declaração Universal dos Direitos Humanos e o artigo 7 do Pacto Internacional dos Direitos Civis e Políticos, que estabelecem que ninguém será submetido à tortura ou a tratamentos ou penas cruéis, desumanos ou degradantes, levando também em consideração a Declaração sobre a Proteção de Todas as Pessoas contra a Tortura e outros Tratamentos ou Penas Cruéis, Desumanos ou Degradantes, adotada pela Assembleia Geral em 9 de dezembro de 1975, desejando tornar mais eficaz a luta contra a tortura e outros tratamentos ou penas cruéis, desumanos ou degradantes em todo o mundo, acordaram no seguinte: Art. 50. 1. Cada Estado Parte tomará as medidas que sejam necessárias de modo a estabelecer sua jurisdição sobre os crimes previstos no artigo 4, nos seguintes casos: a) quando os crimes tenham sido cometido em qualquer território sob a sua jurisdição ou a bordo de um navio ou de uma aeronave registrada no Estado em apreço; b) quando o suposto criminoso for nacional do Estado em apreço; c) quando a vítima for cidadã do Estado em apreço, se este o considerar apropriado. 2. Cada Estado Parte também deverá tomar todas as medidas necessárias para estabelecer sua jurisdição e o Estado não o extradite de acordo com o artigo 8 para qualquer dos Estados mencionados no parágrafo 1 deste artigo. 3. Esta Convenção não exclui qualquer jurisdição criminal exercida de acordo com o direito interno.

${ }^{11}$ Artigo 13 - Cada Estado Parte assegurará que qualquer pessoa que alegue ter sido submetida à tortura em qualquer território sob sua jurisdição tenha o direito de apresentar queixa e ter o seu caso rápida e imparcialmente examinado pelas autoridades competentes do dito Estado. Serão adotadas providências no sentido de assegurar a proteção do queixoso e das testemunhas contra quaisquer maus-tratos ou intimidações resultantes de queixa ou depoimentos prestados.
} 
Em 1989 o Brasil ratificou a Convenção ao editar a lei no 9.455/97, que exemplificou o que se entendia por tortura no âmbito interno da jurisdição. Conforme esta, a tortura poderia ser compreendida como constranger alguém com emprego de violência ou grave ameaça, causando-Ihe sofrimento físico ou mental. A legislação pátria ampliou no texto o sujeito ativo, de modo que qualquer pessoa que realizar um ato atentatório a outrem, possa ser enquadrada na legislação.

\subsection{Tratados Internacionais: a Recepção Voluntária, a sua Necessária Vinculação Depois Que São Ratificados e o Controle Internacional}

As normas encontram-se em uma ordem hierárquica - a pirâmide normativa - que acaba por delimitar os limites materiais e formais do poder normativo. Vitor Hugo Nicastro Honesko ressalta que "se examinarmos a pirâmide normativa de baixo para cima, perceberemos que as normas jurídicas inferiores se encontram fundadas, material e formalmente, em normas jurídicas superiores, da mesma maneira ocorre quando ao contrário ${ }^{12 "}$. Aqui, encontram-se os tratados de direitos humanos no ordenamento pátrio, os quais devem sempre ingressar neste por meio de uma sobrenorma. ${ }^{13} \mathrm{~A}$ partir do momento em que o Estado realiza a ratificação do tratado de direitos humanos, todo o seu conjunto de normas integra as garantias e direitos protegidos constitucionalmente, devendo, então, ter a sua aplicação.

Conforme a Constituição de 1988, o Estado pode realizar sua participação no direito internacional mediante um procedimento que necessita da manifestação de vontade dos poderes Executivo e Legislativo na matéria dos tratados: é a teoria da junção das vontades. Aqui, verifica-se que, caso esta manifestação de vontade não exista, não há que se falar em formação de tratados e seu cumprimento interno. ${ }^{14}$

Para a celebração definitiva de um tratado, fases devem ser cumpridas. Em primeiro lugar, como forma de demonstração de vontade, tem-se a fase da assinatura, na qual acontecem todas as negociações sobre o conteúdo do tratado, que resulta na manifestação expressa do interesse na celebração. Apenas após estas, o tratado é incorporado e acontece o decreto presidencial. Como não existe prazo estipulado para a aprovação congressual, o trâmite pode durar até décadas, dependendo, infelizmente, da conveniência política. Para a celebração definitiva do mesmo, também não há prazo para o Presidente da República, o que faz com que a sua ratificação não seja obrigatória, e sim um ato discricionário.

A norma internacional não será válida enquanto não for editado o Decreto de Promulgação pelo presidente da República e referendado pelo ministro das Relações Exteriores. Neste momento, é incorporado ou recepcionado o tratado internamente. A este respeito, André de Carvalho Ramos destaca:

\footnotetext{
12 HONESKO, 2010. p. 289-305.

${ }^{13}$ HONESKO, 2010. p. 300.

${ }^{14}$ RAMOS, 2014. p. 360.
} 


\section{Humanos e}

Democracia

Esse Decreto inova a ordem jurídica brasileira, tornando válido o tratado no plano interno. Não há prazo para sua edição e até lá o Brasil está vinculado internacionalmente, mas não internamente: esse descompasso enseja a óbvia responsabilização internacional do Brasil. ${ }^{15}$

Verifica-se, aqui, a complexidade de incorporação de um tratado internacional, e a necessidade de manifestação de vontade para que as negociações se iniciem. Assim, não há que se falar de um tratado imposto dentro do ordenamento, o que implica sua obrigatoriedade de cumprimento. Ademais, para o âmbito internacional, todos os atos normativos internos de um Estado devem ser compatibilizados com os compromissos assumidos, sob pena de responsabilização, uma vez que um estado não pode se escusar de cumprir determinada norma sob a argumentação de uma incompatibilidade interna, conforme o artigo 27 da Convenção de Viena sobre o Direito dos Tratados, de 1969.

Em consonância com a compatibilidade interna das normas com o direito internacional, é importante ressaltar ainda que há outra forma de verificação se um tratado está devidamente sendo cumprido: o controle de convencionalidade. Esse consiste em uma análise realizada internamente nos países em relação às normas internacionais quanto à compatibilidade dos atos internos destes, sejam comissivos ou omissivos. De competência dos órgãos internacionais, é realizado pelos tribunais internacionais - e o de convencionalidade de matriz nacional - e consistente no exame das normas internacionais realizado pelos juízes internos. ${ }^{16}$

O controle de convencionalidade internacional será aquele no qual há uma fiscalização dos atos do Estado por órgãos internacionais em relação aos compromissos assumidos internacionalmente. Já o controle de convencionalidade nacional é a verificação da compatibilidade das normas internacionais dentro do ordenamento interno. É de suma importância salientar que o controle nacional não vincula o internacional. ${ }^{17}$ É certo que não serão todas as vezes que o controle de convencionalidade internacional coincidirá com o interno, como é o caso da Lei da Anistia, conforme os dizeres do referido autor:

É óbvio que nem sempre os resultados do controle de convencionalidade internacional coincidirão com os do controle nacional. Por exemplo, um Tribunal interno pode afirmar que determinada norma legal brasileira é compatível com um tratado de direitos humanos; em seguida, um órgão internacional de direitos humanos, ao analisar a mesma situação, pode chegar à conclusão de que a referida lei viola o tratado. ${ }^{18}$

Em virtude de uma possível contrariedade de entendimentos, diante de uma situação concreta, o controle de constitucionalidade final é o internacional, e deste decorre uma segunda denominação - "controle autêntico ou definitivo" -, uma vez que é desta maneira que se chega à premissa de que o tratado foi devidamente cumprido. Assim sendo, sob a visão do direito internacional todos os atos normativos internos de um país são vontades que devem

\footnotetext{
${ }^{15}$ RAMOS, 2014. p 360.

${ }^{16}$ RAMOS, 2014. p. 386-387.

${ }^{17}$ RAMOS, 2014. p. 74.

${ }^{18}$ RAMOS, 2014, p. 630.
} 
ser compatíveis com os seus engajamentos internacionais, de maneira que o Estado não poderá alegar que houve um descumprimento de norma internacional em razão de incompatibilidade com o ordenamento interno. Há uma supremacia de normas. ${ }^{19}$

\subsection{A Incompatibilidade da Convenção Internacional com a Lei da Anistia}

Em meio a um período de regime militar em que os casos de tortura eram cada vez mais frequentes e conhecidos, no ano de 1979 foi promulgada, no Brasil, a Lei no 6.683/79, a Lei da Anistia. Tal Lei trouxe uma possibilidade de anistia a todos aqueles que realizaram crimes políticos ou conexos a estes no período de setembro de 1961 a agosto de 1979, de modo que todos os procedimentos penais envolvidos nos casos ficaram impedidos de realização. A mesma não foi nada mais que uma forma de controle do governo, bem como uma espécie de tentativa de redemocratização na época. ${ }^{20}$

No ano de 1984 a Convenção contra a tortura e outros tratamentos e penas cruéis, desumanas ou degradantes, declarada pela ONU, foi ratificada pelo Brasil, ainda sob a vigência da Lei da Anistia. Com a chegada da Constituição de 1988, e um Estado democrático de direito, incompatibilidades com a anistia concedida foram surgindo, bem como a contrária disposição desta com a Convenção e suas disposições expressas. Em primeiro lugar, cumpre retomar um ponto pertinente à discussão para o direito internacional, uma vez que o Estado assumiu um compromisso perante este, e não há possibilidades de ressalvas quanto à obrigatoriedade em seu cumprimento, inclusive quando são utilizadas "desculpas com base na Constituição" ou ordenamento interno. Sob este argumento, o Supremo entendeu que a Lei da Anistia era constitucional, criada em um específico contexto histórico, sem possibilidade de revogação.

A Lei da Anistia não foi retirada do ordenamento jurídico mesmo diante de uma Arguição de Descumprimento de Preceito Fundamental (ADPF no 153, rel. min. Eros Grau), gerando efeitos até os dias atuais. Nos questionamentos feitos por esta, encontravam-se a recepção da Lei da Anistia pela Constituição de 1988, de modo que a norma tivesse sua interpretação literal afastada, sendo, então, analisada sob a ótica constitucional. ${ }^{21} \mathrm{O}$ Supremo Tribunal Federal considerou, ainda, que se trata de um ato com a participação da sociedade, e, conforme a previsão na Emenda Constitucional № 26/85, em seu artigo 4ํ, §1ํㅡ, a validação da lei ocorreu, gerando também a recepção pela Constituição de 1988.

4으 É concedida anistia a todos os servidores públicos civis da Administração direta e indireta e militares, punidos por atos de exceção, institucionais ou complementares. §10 É concedida, igualmente, anistia aos autores de crimes políticos ou conexos, e aos dirigentes e representantes de organizações sindicais e estudantis, bem como aos servidores civis ou empregados que hajam sido demitidos ou dispensados por motivação exclusivamente política, com base em outros diplomas legais.

\footnotetext{
19 RAMOS, 2014, p. 387.

20 Secretaria Especial dos Direitos Humanos, 2007. p. 23. (Bibliográfica).

${ }^{21}$ STF, ADPF 153
} 


\title{
Democracia
}

Humanos e

Em seus dizeres sobre a ADPF, o relator ministro Eros Grau, durante o seu voto, ressalta que:

\begin{abstract}
A chamada Lei da Anistia veicula uma decisão política assumida naquele momento - o momento da transição conciliada de 1979. A Lei 6.683 é uma lei-medida, não uma regra para o futuro, dotada de abstração e generalidade. Há de ser interpretada a partir da realidade no momento em que foi conquistada. A Lei 6.683/1979 precede a Convenção das Nações Unidas contra a Tortura e Outros Tratamentos ou Penas Cruéis, Desumanos ou Degradantes - adotada pela Assembleia Geral em 10 de dezembro de 1984, vigorando desde 26 de junho de 1987 - e a Lei 9.455, de 7 de abril de 1997, que define o crime de tortura; e o preceito veiculado pelo art. 5, XLIII, da Constituição - que declara insuscetíveis de graça e anistia a prática da tortura, entre outros crimes - não alcança, por impossibilidade lógica, anistias anteriormente a sua vigência consumadas. A Constituição não afeta leis-medida que a tenham precedido. ${ }^{22}$
\end{abstract}

As violações aos direitos humanos ocorridas no período "protegido" pela Lei da Anistia não se tratam de um fato controverso e esta lei; logo, em seu primeiro artigo, demonstra uma incompatibilidade com a Convenção e com a Constituição brasileira, a qual não mencionou, em qualquer momento, o instituto, mas, sim, uma importância à punição de qualquer violação de direitos humanos e da personalidade.

A Declaração Universal dos Direitos Humanos foi um dos acontecimentos mais importantes para a proteção dos direitos humanos, servindo como marco inicial para outros tratados com finalidades conexas, passando, então, a existir uma movimentação mundial de proteção de tais direitos. É importante lembrar que a Declaração Universal nasceu após o término da Segunda Guerra Mundial, para que nunca mais acontecesse o desrespeito à dignidade da pessoa humana. Acontece que em momentos de vulnerabilidade da sociedade, a dignidade da pessoa é aviltada; como exemplo, vê-se a vida indigna dos moradores de rua, dos presos em presídios e cadeias em condição sub-humana e a mortandade sem atendimento hospitalar, entre outras situações.

A dignidade humana é ferida não por falta de normas, mas por ausência de aplicabilidade das existentes. A tortura humana acontece mesmo com grande número de convenções para resguardar tais direitos. A tortura para os crimes políticos aconteceu a partir de 1964, quando, desde 1948 (momento em que surgiu a declaração universal dos direitos humanos), os direitos humanos estavam protegidos. O Brasil passou, porém, a proteger tais somente quando os transformou em direitos fundamentais com a promulgação da Constituição Federal de 1988. Com tal demora, grande demanda de ações foi movida com o intuito de evidenciar os erros do Estado com a tortura por crimes políticos e a indenização pelos danos causados à dignidade da vítima.

O caso mais emblemático, em relação ao Brasil, foi o já mencionado Caso Gomes Lund ou Guerrilha do Araguaia, no qual a Corte Interamericana julgou a invalidade da Lei da Anistia e determinou a punição dos responsáveis pelos crimes ocorridos. Mesmo diante de tal julgamento, o STF manteve a posição de que tal decisão não o vincularia, sem qualquer efeito surtido. Em análise ao julgado, percebe-se que o STF, analisando a validade do dispositivo,

22 STF, ADPF 153. 
optou pelo "caráter bilateral da anistia, ampla e geral", afirmando, ainda, que "o argumento descolado da dignidade da pessoa humana para afirmar a invalidade da conexão criminal que aproveitaria aos agentes políticos que praticaram crimes comuns contra opositores políticos, presos ou conexão sui generis, própria ao momento histórico da transição para a democracia. Ignora, no contexto da lei no $6.683 / 79$, o sentido ou os sentidos correntes na doutrina da chamada conexão criminal; refere o que 'se procurou', segundo a inicial, foi a anistia criminal de natureza política aos agentes do Estado encarregados da repressão. A lei estendeu a conexão aos crimes praticados pelos agentes do Estado contra os que lutavam contra o Estado de exceção, a chamada Lei da Anistia veicula uma decisão política assumida naquele momento". ${ }^{23}$

Países que aderiram à Convenção, bem como aqueles que também passaram por períodos transitórios em seu regime, adequaram-se às diretrizes internacionais e se encontram em um período de incentivo ao rompimento de um passado autoritário e violador de direitos, investigando os casos conforme os pedidos de particulares. Tal procedimento nada mais é do que um incentivo à confiança do cidadão com o Estado. No Brasil, as adequações andaram a passos lentos.

No ano de 2010, com a sentença do caso Gomes Lund e Outros, diversas imposições pela Corte foram impostas, de modo que o Brasil passasse a investigar as mortes e cumprisse, de fato, os ditames da Convenção incorporada no âmbito interno. Neste momento, foram criadas a Lei do Acesso à Informação e a Lei da Comissão Nacional da Verdade (no 12.527/11 e 13.028/11, respectivamente), ambas com o intuito de dar publicidade e transparência nos casos ocorridos durante o regime militar, o qual causou dezenas de mortes, sem a sua devida explicação. Tais leis têm, ainda, o objetivo de evitar que estes casos se repitam.

\section{ARGUIÇÃO DE DESCUMPRIMENTO DE PRECEITO FUNDAMENTAL 153}

Em 21 de outubro de 2008, o Conselho Federal da Ordem dos Advogados do Brasil interpôs a ADPF, de número 153, contra a inconstitucionalidade da validação da Lei da Anistia Brasileira, referente às violações de direitos humanos dentro do período abrangido pela lei. A fundamentação foi o artigo 5ㅇ, XLIII da Constituição Federal de 1988, que estabelece que a tortura é um crime imprescritivel, o que não permitiria que os efeitos da anistia se concretizassem no caso.

Conforme os dizeres da ADPF:

Acrescenta não ser possível, consoante o texto da Constituição do Brasil, considerar válida a interpretação segundo a qual a Lei n. 6.683 anistiaria vários agentes públicos responsáveis, entre outras violências, pela prática de homicídios, desaparecimentos forçados, abuso de autoridade, lesões corporais, estupro e atentado violento ao pudor. Sustenta que essa interpretação violaria frontalmente diversos preceitos fundamentais. A eventual declaração, por esta Corte, do recebimento do $\S 1$ 10 do artigo $1^{\circ}$ da Lei 6.683 implicaria, segundo o arguente, desrespeito [i] ao dever, do Poder Público, de não ocultar a verdade; [ii] aos princípios democrático e republicano; [iii] ao princípio da dignidade da pessoa humana.

\footnotetext{
${ }_{23}$ STF, ADPF 153, p. 33, 34.
} 


\section{Humanos e \\ Democracia}

O relator ministro Eros Grau, durante o seu voto, afirmou:

A chamada Lei da anistia veicula uma decisão política assumida naquele momento - o momento da transição conciliada de 1979. A Lei 6.683 é uma lei-medida, não uma regra para o futuro, dotada de abstração e generalidade. Há de ser interpretada a partir da realidade no momento em que foi conquistada. A Lei 6.683/1979 precede a Convenção das Nações Unidas contra a Tortura e Outros Tratamentos ou Penas Cruéis, Desumanos ou Degradantes - adotada pela Assembleia Geral em 10 de dezembro de 1984, vigorando desde 26 de junho de 1987 - e a Lei 9.455, de 7 de abril de 1997, que define o crime de tortura; e o preceito veiculado pelo art. 5, XLIII, da Constituição - que declara insuscetíveis de graça e anistia a prática da tortura, entre outros crimes - não alcança, por impossibilidade lógica, anistias anteriormente a sua vigência consumadas. A Constituição não afeta leis-medida que a tenham precedido.

Embasado na previsão contida na Emenda Constitucional de número 26/85, a qual teve a invocação da Assembleia Constituinte, o STF entendeu que houve a recepção da Constituição de 1988 da Anistia. ${ }^{24} \mathrm{O}$ entendimento é de que a anistia concedida nos dias de hoje não mais seria a prevista na lei $6.683 / 79$, mas, sim, a do artigo 4 o $\S 1$ o da emenda, o que tornaria inútil o questionamento de tal dispositivo, uma vez que houve a anuência da ordem constitucional de 88.

De acordo com o entendimento dos julgadores: o texto da lei ordinária de 1979 resultou substituído pelo texto da emenda constitucional. A emenda constitucional, produzida pelo Poder Constituinte originário, constitucionaliza a anistia de modo tal que, estivesse o $\S 1$ o desse artigo 4 을 da emenda sendo questionado nesta ADPF, o que não ocorre, poder-se-ia tê-la como incompatível com o que a Assembleia Nacional Constituinte produziu na Constituição de 1988. Surge, aqui, o entendimento de que a anistia se encontra nos ditames da presente ordem constitucional, e compõe-se na origem da nova norma fundamental.

O STF, conhecido como guardião da Constituição, é aquele que realiza o controle de constitucionalidade interno. Com este poder que Ihe foi conferido, a anistia foi recepcionada pelo ordenamento vigente. Ocorre que, de acordo com a Convenção Americana de Direitos Humanos e dos Tratados de Direitos Humanos, os quais têm como guardião a Corte de San José, a Lei da Anistia não pode ser invocada pelos atuantes na ditadura. Nos dizeres de André de Carvalho Ramos:

Assim, ao mesmo tempo em que se respeita o crivo de constitucionalidade do STF, deve ser incorporado o crivo de convencionalidade da Corte Interamericana de Direitos Humanos. Todo ato interno (não importa a natureza ou origem) deve obediência aos dois crivos. Caso não supere um deles (por violar direitos humanos), deve o Estado envidar todos os esforços para cessar a conduta ilícita e reparar os danos causados. ${ }^{25}$

\footnotetext{
$\overline{{ }^{24} \text { CASTILHO, 2012. p. } 273 .}$

${ }^{25}$ RAMOS, 2014.p. 630.
} 
O Ministério da Defesa afirmou que a ADPF seria incabível diante da prescrição dos crimes em uma maneira geral, argumento este que vem sendo utilizado nas ações de reparação proposta nos dias atuais. De outro lado, é inerente o questionamento diante de tal argumento, uma vez que, se houve a recepção de tais preceitos no ordenamento vigente, a tortura encontra-se no rol de crimes imprescritíveis.

Segundo Pontes de Miranda ${ }^{26}$ : "'a finalidade da anistia é a mesma da lei criminal com sinais trocados'; e com ela, 'olvida-se o ato criminal, com a consequência de se lhe não poderem atribuir efeitos de direito material ou processual. Aconteceu o ato; agora, indo-se ao passado, mesmo onde ele está, acontece juridicamente o desaparecer, deixar de ser, não ser'". Por fim, é necessário não esquecer, para que nunca mais as coisas voltem a ser como foram no passado.

\subsection{Caso Gomes Lund - o Reconhecimento da Responsabilidade Brasileira e a Falta de Adequação das Decisões com a Convenção Internacional Ratificada}

De acordo com o contido na Jurisprudência da Corte Interamericana de Direitos Humanos, o caso refere-se à responsabilidade do Estado pela "detenção arbitrária, tortura e desaparecimento forçado de 70 pessoas, entre membros do partido comunista e camponeses da região, resultado de operações do Exército brasileiro empreendidas entre 1972 e 1975 com o objetivo de erradicar a Guerrilha do Araguaia, no contexto da ditadura militar."27 Tal movimento consistia na construção de um exército popular contra o regime vigente, o qual foi combatido pelo exército, marinha, forças aéreas e polícia militar e federal. Em um primeiro momento, a ordem era apenas para conter os integrantes do movimento, mas, sob as ordens do general Médici, a ordem oficial passou a ser de eliminação dos capturados. Ao final do ano de 1974 não havia mais guerrilheiros no Araguaia, e, ainda, constam em registros que os corpos foram desenterrados e queimados ou atirados no rio da região. ${ }^{28} \mathrm{O}$ governo impôs silencio no caso.

Na data de 18 de Julho de 2006, o Grupo Tortura Nunca Mais do Rio de Janeiro, a Comissão de Familiares de Mortos e Desaparecidos Políticos do Instituto de Estudos da Violência do Estado e o Centro pela Justiça e o Direito Internacional, apresentaram suas solicitações e provas em relação aos desaparecimentos forçados e à impunidade do Estado ante a estas. O Estado, por sua vez, interpôs três exceções preliminares, sendo a incompetência do tribunal para examinar a demanda, em razão do tempo dos fatos; o não esgotamento dos recursos internos; e o não interesse processual da Comissão e de seus representantes. Ainda, contestou a demanda.

A Corte considerou que a partir do momento em que o Brasil reconheceu a competência contenciosa da Corte Interamericana, esta teria competência para decidir sobre fatos posteriores. Em sua verificação, a Corte constatou graves violações de direitos humanos no caso do Araguaia, uma vez que os desaparecimentos forçados ferem os princípios do Sistema Interamericano de Direitos Humanos, de forma que foi alcançado um caráter de jus cogens no caso. Cumpre ressaltar que em momento algum foi negado pelo Estado o desaparecimento das vítimas, mas, sim, controvérsias a respeito da Convenção Americana sobre Direitos Humanos, a qual teve a sua ratificação pelo Estado brasileiro em 1992, dando plenos poderes para uma averiguação da compatibilidade da Lei da Anistia.

\footnotetext{
${ }^{26}$ MIRANDA, 1970.

${ }^{27}$ CORTE INTERAMERICANA DE DIREITOS HUMANOS.

${ }^{28}$ BIBLIOTECA DO MINISTÉRIO DA JUSTIÇA, 2010. p. 33.
} 


\section{Humanos e \\ Democracia}

O Estado brasileiro procurou formas de reparação do ocorrido, dentre elas a promulgação da Lei no 9.140/95 e a publicação do direito à memória e à verdade, mas, segundo a Comissão, estas não foram suficientes para o caso em questão. Por fim, foi decidido, com unanimidade pela Corte, que todos os efeitos causados pela Lei da Anistia não podem ser considerados obstáculos para as investigações, assim como a mesma fere as convenções ratificadas pelo Estado brasileiro.

Em relação à responsabilidade sobre o caso Araguaia, foi reconhecida a responsabilidade do Estado nas violações de direitos humanos ocorridas, bem como da dignidade humana. Todos os atos foram contrários aos dispostos nas convenções. Por unanimidade foi disposto que o Estado não deveria medir esforços para realizar as buscas e investigações das vítimas, bem como oferecer todo o suporte necessário para os seus familiares, sejam tratamentos médicos ou psiquiátricos, realizar um ato público para reconhecer a sua responsabilidade e não deixar de fazer novas buscas para esclarecimento dos familiares.

A Corte foi clara ao dar o seu parecer, afastando os efeitos da Lei da Anistia, uma vez que esta feria diretamente todos os tratados e convenções ratificados pelo Estado brasileiro, reconhecendo a responsabilidade integral deste no dever de reparar, e por fim, no quesito de supervisionar o fiel cumprimento da sentença. A mesma foi dada no dia 24 de novembro de 2010.

\section{CONTROLE DE CONVENCIONALIDADE}

O controle de convencionalidade é a análise realizada internamente nos países em detrimento das normas internacionais quanto à compatibilidade dos atos internos destes, sejam comissivos ou omissivos. André de Carvalho Ramos realiza uma subdivisão deste controle em: convencionalidade de matriz internacional - aquele que é competência dos órgãos internacionais e é realizado pelos tribunais internacionais -; e o de convencionalidade de matriz nacional - consiste no exame das normas internacionais realizado pelos juízes internos. Em outras palavras, controle de convencionalidade internacional será aquele em que há uma fiscalização dos atos do Estado em relação aos compromissos assumidos internacionalmente. Já o controle de convencionalidade nacional é a verificação da compatibilidade das normas internacionais dentro do ordenamento interno. É de suma importância salientar que o controle nacional não vincula o internacional. ${ }^{29}$ É certo que não serão todas as vezes que o controle de convencionalidade internacional coincidirá com o interno, como é o caso da Lei da Anistia, conforme os dizeres do referido autor:

É óbvio que nem sempre os resultados do controle de convencionalidade internacional coincidirão com os do controle nacional. Por exemplo, um Tribunal interno pode afirmar que determinada norma legal brasileira é compatível com um tratado de direitos humanos; em seguida, um órgão internacional de direitos humanos, ao analisar a mesma situação, pode chegar à conclusão de que a referida lei viola o tratado. ${ }^{30}$

Em virtude de uma possível contrariedade de entendimentos diante de uma situação concreta, o controle de constitucionalidade final é o internacional, e, deste, decorre uma segunda denominação, como "controle autentico ou definitivo", uma vez que é desta maneira

\footnotetext{
${ }^{29}$ RAMOS, 2014.

30 RAMOS, 2014, p. 630.
} 
que se chega à premissa de que o tratado foi devidamente cumprido. Assim sendo, sob a visão do direito internacional todos os atos normativos internos de um país são vontades que devem ser compatíveis com os seus engajamentos internacionais, de maneira que o Estado não poderá alegar que houve um descumprimento de norma internacional em razão da incompatibilidade com o ordenamento interno, pois há uma supremacia de normas.

\section{A ANISTIIA NA JURISPRUDÊNCIA ATUAL}

Os casos em que houve a invocação do Judiciário para a reparação de danos causados em relação ao período compreendido da Lei da Anistia, não se limitaram àqueles que chegaram à corte internacional, bem como não terminaram no momento em que foi proferida a sentença do caso Herzog. Pelo STF, no julgamento da ADPF 153, o argumento de prescrição continuou sendo utilizado. Conforme o julgamento da citada ação: "O Ministério da Defesa afirma por fim, contra o cabimento da ADPF, a inutilidade de eventual decisão de procedência. Isso por que os crimes - ainda que não anistiados - estariam prescritos. Caso viesse a ser julgada procedente, dela não resultaria nenhum efeito prático".

A argumentação utilizada neste ponto foi reaproveitada em julgados posteriores, fazendo com que, de uma maneira ou de outra, os crimes ocorridos na vigência da lei ainda não possuam a devida posição do Judiciário. Cumpre destacar que se a presente lei foi recepcionada pela Constituição de 1988, de acordo com o alegado reiteradas vezes, o crime de tortura ainda não seria suscetível de prescrição, embasada na supremacia de normas existentes. A ordem constitucional, bem como a posterior lei $n=8.072 / 90$, prevê tal espécie de crime no rol dos imprescritiveis, sem possibilidade de anistia.

Na decisão proferida no HC 110698 - STF -, referente à Guerrilha do Araguaia, foi entendido que a investigação tem o sentido apenas de propiciar o conhecimento da verdade histórica para todas as gerações, de ontem e de hoje, no exercício do denominado "dever de memória", o que não se submete a prazos de prescrição. O mesmo não acontece com a persecução penal em relação a (supostos) fatos incluídos na anistia da Lei 6.683, de 19/12/1979 e, de resto, sepultados penalmente pela prescrição. ${ }^{31}$

\footnotetext{
31 “PENAL E PROCESSUAL PENAL. HABEAS CORPUS. CRIME DE SEQUESTRO E CÁRCERE PRIVADO. GUERRILHA DO ARAGUAIA. LEI DA ANISTIA (LEI 6.683/79). AÇÃO DE DESCUMPRIMENTO DE PRECEITO FUNDAMENTAL 153 - DF. POSSIBILIDADE JURÍDICA DO PEDIDO. PRESCRIÇÃO DA PRETENSAO PUNITIVA. CONSTRANGIMENTO ILEGAL. TRANCAMENTO DA AÇÃO PENAL. 1. Imputa a denúncia ao paciente o cometimento de crimes de seqüestro e cárcere privado (art. 148, § 2o, c/c o art. 69 - CP), cuja consumação, iniciada em 1974, persistiria até o presente, em relação a cinco integrantes de grupo político com atuação clandestina durante o regime militar (Guerrilha do Araguaia), cujo paradeiro é desconhecido. 2. Dispõe a Lei 6.683/79, considerada válida pelo STF em face da Constituição (1988), no julgamento da Ação de Descumprimento de Preceito Fundamental no 153 - DF, que 'É concedida anistia a todos quantos, no período compreendido entre 02 de setembro de 1961 a 15 de agosto de 1979, cometeram crimes políticos ou conexos com estes.' (art. 1ㅇ), e que 'Consideram conexos, para efeito deste artigo, os crimes de qualquer natureza relacionados com os crimes políticos ou praticados por motivação política.' (§ 1ㅇ). 3. A persecução penal, vista em face do julgamento do STF, carece de possibilidade jurídica e (assim não fora) de lastro de legalidade penal, dada a evidente prescrição da pretensão punitiva estatal diante do longo tempo decorrido, de então (1974) a esta parte, consubstanciando, por qualquer dos fundamentos, sobretudo pelo primeiro, evidente constrangimento ilegal ao paciente (art. 648, I - CPP). 4. A decisão da Corte Interamericana de Direitos Humanos, impondo ao Estado Brasileiro a realização, perante a sua jurisdição ordinária, de investigação penal dos fatos ocorridos na chamada Guerrilha do Araguaia, não interfere no direito de punir do Estado, nem na eficácia da decisão do STF sobre a matéria, na ADPF 153/DF. 5. A investigação tem o sentido apenas de propiciar o conhecimento da verdade histórica, para todas as gerações, de ontem e de hoje, no exercício do denominado 'dever de memória', o que não se submete a prazos de prescrição. Não o da abertura de persecução penal em relação a (supostos) fatos incluídos na anistia da Lei 6.683 , de 19/12/1979 e, de resto, sepultados penalmente pela prescrição. 6 . 0 trancamento da ação penal pela via do habeas corpus somente é autorizado na evidência de uma situação de excepcionalidade, vista como 'a manifesta atipicidade da conduta, a presença de causa de extinção da punibilidade do paciente ou a ausência de indícios mínimos de autoria e materialidade delitivas' (HC 110698 - STF). Hipótese que ora se apresenta, dada a evidente falta de justa causa para a ação penal. 7. Concessão da ordem de habeas corpus. Trancamento da ação penal (art. 648, I - CPP)."
} 


\section{Democracia}

Com base no julgado, vê-se que a posição dos julgadores é de trazer os fatos ocorridos para conhecimento histórico, porém, pelo tempo em que os crimes aconteceram, nada poderá ser feito penalmente, conforme a ocorrência de uma suposta prescrição.

A dignidade da pessoa humana tem valor imensurável para a pessoa, e, por isso, o direito a protege como Princípio Constitucional quando, na Constituição Federal de 1988, acolheu o convencionado pela declaração dos direitos humanos de 1948, transformando-se para o direito pátrio como direitos fundamentais. Não é possível pensar, nos dias atuais, em reviver um período de trevas aos direitos. A tortura sofrida em tempos remotos marcou a história com sangue, com medo, desrespeito, mordaças, desaparecimentos, perda da liberdade de expressão, entre outros direitos.

A história provou que as torturas sofridas em período ditatorial neste país precisam ser examinadas diante do inferno que se instalou em determinado período. É preciso analisar quais normas, convenções e declarações internacionais foram infringidas e quais os efeitos nocivos à vida humana. Danos físicos, morais, psíquicos e mentais foram causados às vítimas em um período de escuridão nos direitos, quando o poder massacrou aqueles que se colocaram contrários ao mesmo, e as torturas foram aplicadas, criando a desesperança, a perda da liberdade, da vida e da dignidade. A tortura foi utilizada em situações de desigualdades, de destruição de valores, de projetos de vida, ferindo a democracia e a liberdade. A Lei da Anistia colocou um manto de impunidade sobre condutas desumanas e cruéis, mantendo-se incólume sob a proteção da prescrição. É preciso lutar pelos direitos e ver estampar nos olhos das pessoas a esperança de vida, de liberdade interior e de expressão; e a certeza que os direitos fundamentais a protegerão em sua dignidade.

\section{CONCLUSÃO}

O Brasil viveu um longo período de ditadura militar, quando os direitos à proteção à dignidade humana foram afrontados, com prisões e condenações sumárias sem o direito ao contraditório, prisões ilegais, torturas, mortes e pessoas desaparecidas por crimes políticos e conexos em total confronto ao respeito e proteção à dignidade humana, mesmo estando, em esfera internacional, tal direito protegido pela Declaração Universal dos Direitos Humanos.

As nuvens escuras da ditadura e da tortura no Brasil por crimes políticos sempre estiveram à espreita, nunca totalmente dissipadas, diante de gritos desconexos e de pessoas com vendas nos olhos que tentam reviver tal período negro da história. É preciso analisar o contexto histórico, político e social vivido em período ditatorial, no qual a vida humana não tinha valor, e a preservação do poder levava à tortura toda pessoa que divergisse em pensamento e praticasse qualquer ato que pudesse expor o estado de injustiça que era praticado.

As torturas foram praticadas em total confronto com os direitos humanos tutelados pela Declaração Universal dos Direitos Humanos de 1948 e da Convenção Internacional de 1984, que foi acolhida pela legislação pátria. O período de escuridão nos direitos existiu até o momento em que a Constituição Federal, promulgada em 1988, instituiu o Princípio da Dignidade Humana, protegendo a pessoa em seus valores morais e projetos interiores. 
A Lei 6.683/79 concedeu a anistia a todos quantos, no período compreendido entre 2 de setembro de 1961 e 15 de agosto de 1979, cometeram crimes políticos ou conexo com estes, crimes eleitorais, aos que tiveram seus direitos políticos suspensos e aos servidores da Administração Direta e Indireta, de fundações vinculadas ao poder público, aos Servidores dos Poderes Legislativo e Judiciário, aos Militares e aos dirigentes e representantes sindicais, punidos com fundamento em Atos Institucionais e Complementares, lembrando que era considerado crime político pensar de forma diferente do partido que estava no poder. Tal lei protegeu os agressores, aqueles que torturaram sob o manto da lei.

Sob a visão do Direito Internacional, todos os atos normativos internos de um país são vontades que devem ser compatíveis com os seus engajamentos internacionais, de maneira que não se poderá alegar que houve um descumprimento de norma internacional em razão da incompatibilidade com o ordenamento interno, pois há uma supremacia de normas. Explica-se tal visão pela prática de tortura mesmo havendo normas internacionais a coibi-la. Somente após a Constituição Federal recepcionar tais normas, tais direitos passam a ser protegidos.

Com a sentença do caso Gomes Lund e Outros, diversas imposições pela Corte foram impostas, de modo que o Brasil passasse a investigar as mortes e cumprisse, de fato, os ditames da Convenção incorporada no âmbito interno. Em razão de tal imposição, foram criadas a Lei do Acesso à Informação e a Lei da Comissão Nacional da Verdade (no 12.527/11 e 13.028/11, respectivamente), ambas com o intuito de dar publicidade e transparência aos casos ocorridos durante o regime militar, o qual causou dezenas de mortes sem a devida explicação. Tais leis têm, ainda, o objetivo de evitar que estes casos se repitam.

A dignidade humana precisa ser objeto de defesa contínua. Não se pode esquecer dos efeitos nocivos à sociedade brasileira e à vida humana que as torturas aplicadas no período da ditadura militar geraram. Danos físicos, morais, psíquicos e mentais foram os frutos de tal violência em um período de escuridão nos direitos, quando o poder massacrou aqueles que se colocaram contrários ao mesmo. As torturas criaram a desesperança, a perda da liberdade, da vida e da dignidade. Ela foi utilizada em situações de desigualdades, de destruição de valores, de projetos de vidas, ferindo a democracia e a liberdade. A Lei da Anistia colocou um manto de impunidade sobre aqueles que praticaram as torturas, condutas desumanas e cruéis, mantendo-se incólume sob a proteção da prescrição. É preciso lutar pelos direitos e ver estampar nos olhos das pessoas a esperança de vida, de liberdade interior e de expressão; e a certeza que os direitos fundamentais a protegerão em sua dignidade.

\section{REFERÊNCIAS}

ÂMBITO JURÍDICO. A incorporação da convenção contra a tortura e outros tratamentos ou penas cruéis, desumanos ou degradantes pelo Estado brasileiro em consonância com a justiça global. Disponível em: http://www. ambito-juridico.com.br/site/index.php?n_link=revista_artigos_leitura\&artigo_id=9862. Acesso em: 3 jun. 2018. ARBEX, Daniela. Holocausto brasileiro: vida, genocídio e 60 mil mortes no maior hospício do Brasil. São Paulo: Geração, 2013. 230 p.

ARNS, Dom Paulo Evaristo. Brasil: nunca mais: um relato para a história. 32. ed. Petrópolis, RJ: Vozes, 2001. BIBLIOTECA DO MINISTÉRIO DA JUSTIÇA. Conselho de defesa dos direitos da pessoa humana: uma história de resistência e luta pelos direitos humanos no Brasil. Brasília: Biblioteca do Ministério da Justiça, 2010. 280 p. 


\section{Humanos e}

Democracia

BRASIL. Supremo Tribunal Federal. Arguição de Descumprimento de Preceito Fundamental no 153. Ministro relator Eros Grau. Arguente: Conselho Federal da Ordem dos Advogados do Brasil. Arguidos: Presidente da República e Congresso Nacional. Brasília, 29 de abril de 2010. In: Diário de Justiça Eletrônico, n. 145/2010. 6 ago. 2010.

BUENO, Francisco da Silveira. Minidicionário da língua portuguesa. São Paulo: FTD, 1996. 703 p.

CASADO FILHO, Napoleão; BIANCHINI, Alice; GOMES, Luiz Flávio. Direitos humanos fundamentais. São Paulo: Saraiva, 2012. 154 p.

CASTILHO, Ricardo. Direitos humanos: sinopses jurídicas. São Paulo: Saraiva, 2012.

CONSULTOR JURÍDICO. A lei de anistia viola convenções de direitos humanos. Disponível em: http://www.conjur. com.br/2011-mar-10/coluna-Ifg-lei-anistia-viola-convencoes-direitos-humanos. Acesso em: 3 jun. 2018.

DEPARTAMENTO DE ASSUNTOS JURÍDICOS INTERNACIONAIS. Convenção interamericana para prevenir e punir a tortura. Disponível em: http://www.oas.org/juridico/portuguese/treaties/a-51.htm. Acesso em: 3 jun. 2018.

DIREITOS FUNDAMENTAIS. Guerra de gigantes: stf versus cidh (lei de anistia). Disponível em: https://direitosfundamentais.net/2011/02/17/guerra-de-gigantes-stf-versus-cidh-lei-de-anistia/. Acesso em: 3 jun. 2018.

DIMOULIS, Dimitri Leonardo Martins. Teoria Geral dos Direitos Fundamentais. São Paulo: Revista dos Tribunais, 2007.

HONESKO, Vitor Hugo Nicastro. A proibição da tortura no âmbito global e seu impacto no sistema jurídico brasileiro. In: PIOVESAN, Flávia; IKAWA, Daniela. Direitos humanos: fundamento, proteção e implementação. Curitiba: Juruá, 2010. p. 289-305. Cap. 3.

JURICIC, Paulo. Crime de tortura. São Paulo: Juarez de Oliveira, 1999. 180 p.

MAZZUOLI, Valério de Oliveira. Curso de direitos humanos. São Paulo: Método, 2014.

MAZZUOLI, Valério de Oliveira. Crimes da ditadura militar: uma análise à luz da jurisprudência atual da Corte Interamericana de Direitos Humanos. São Paulo: Revista dos Tribunais, 2011. p. 226-242.

MENEZES, Olindo. TRF-1 - Habeas Corpus. Disponível em: https://trf-1.jusbrasil.com.br/jurisprudencia/24787506/habeas-corpus-hc-680639220124010000-pa-0068063-9220124010000-trf1/inteiro-teor-112223021. Acesso em: 3 jun. 2018

MIRANDA, Pontes de. Comentários à Constituição de 1967, tomo I. Revista dos Tribunais: São Paulo, 1970.

NÚCLEO DE DIREITOS HUMANOS do Departamento de Direito da Pontifícia Universidade Católica do Rio de Janeiro (org.). Jurisprudência da Corte Interamericana de direitos humanos: direito à vida, anistias e direito à verdade. Rio de Janeiro: Prol Editora Gráfica, 2014. 637 p.

PIOVESAN, Flávia; IKAWA, Daniela (org.). Direitos humanos: fundamento, proteção e implementação. Curitiba: Juruá, 2010. 975 p.

RAMOS, André de Carvalho. Curso de direitos humanos. São Paulo: Saraiva, 2014.

SECRETARIA ESPECIAL DOS DIREITOS HUMANOS. Direito à verdade e à memória: comissão especial sobre mortos e desaparecidos políticos. Brasília: Comissão Especial Sobre Mortos e Desaparecidos Políticos, 2007. 502 p. (Bibliográfica). 